\title{
Flexible and Innovative Learning Spaces: An Exploration of Parental Perspectives on \\ Change, Consultation and Participation
}

Leon Benade

Auckland University of Technology, New Zealand

European Educational Research Journal.

https://doi.org/10.1177/14749041211041204

\begin{abstract}
The role played by innovative educational environments to support learning for the $21^{\text {st }}$ century has attracted the interest of the OECD at the global governance level and at the national policy level internationally. This article draws on global, European and Australasian research and data from a qualitative study of consultation and participation in the development of Innovative and Flexible Learning Spaces in the New Zealand context. It focuses specifically on the role of parents, drawing data from relevant policies and documents, a parent questionnaire, and interviews of parents, architects and Ministry of Education (MOE) Delivery Managers, responsible for delivering large capital works projects. While the architect participants believe their bold designs are inspirational and promote new pedagogical styles, and positive relationships, some parents view these open-plan learning areas (and associated pedagogies) as needlessly experimental, placing the needs and education of their children at risk. Delivery Managers are focussed on seeing the projects to conclusion, on time and on budget. The critical analysis considers the findings in relation to the research question and reflects on the dual themes of innovation and risk. Further questions for research are suggested.
\end{abstract}

\section{Keywords}

Innovative Learning Environments, Parental participation, School architecture, Open-plan learning, Flexible Learning Space

\section{Introduction}

This article is framed by the question, 'in what way are parents invited to participate in design planning processes, and how and what do they contribute to this process?' This question was considered in interviews of selected parents, architects and property Delivery (project) Managers, and was embedded in a small-scale questionnaire completed by 44 parents. Its context is the growing manifestation of innovative educational facilities' designs that take account of the increasing influence of digital technology, the changing dispositions, attitudes and learning behaviours of young people, and the consequent influence of these various developments on pedagogy. While the specific context of the research reported in this article is New Zealand, the published research underpinning this article shows that the subject of pedagogical change and innovation in education is widespread. The influence of the supranational OECD is shown, for example, in Portugal's SSMP (Veloso et al., 2014) as much as it 
was reflected by MOE policy in New Zealand in the period 2011-2018 (Author, 2017b). The intense interest in developing innovative educational facilities and concerns with changing teacher behaviours is reflected in research related to the Scandinavian region (Leiringer and Cardellino, 2011); Iceland (Sigurðardóttir and Hjartarson, 2016); and England (Mahony and Hextall, 2013; Tse et al. 2015; Woolner et al, 2012; Woolner et al., 2018). In Australia, the ILETC project (example, Imms, et al., 2017) has garnered significant international attention. This article also sheds light on the themes of innovative change and risk in the context of refurbished and newly-built schools, particularly from a parental perspective. It is developed from an exploratory study of consultation and participation in the (re)design of nontraditional, flexible school and classroom designs, and associated changes in pedagogical practice in the New Zealand context. The research question posed in the first line of this introduction is based on one of the questions arising from the larger study. The New Zealand Ministry of Education (MOE) recognises the importance of consultation when establishing innovative learning environments ${ }^{1}$ (TKI, nd. (a), 'Involve students' and 'Work with parents and whanau'2). In 2013, when its ILE building programme was beginning to gain traction, then Minister of Education, Hekia Parata, claimed that communities would 'have a say' in the development of new schools through their Establishment ${ }^{3}$ Boards (Parata, 2013). While this study is premised on the view that participation by community members (broadly understood) is positive (though not without pitfalls), evidence in the case of newly built schools in New Zealand contradicts, however, official discourse, as Establishment Boards fail to represent 'the community' by excluding key stakeholders such as the school leadership members, teachers, and students (Wells et al., 2018). In the case of school rebuilds, renovations and retrofits, evidence in this study indicates that substative consultation is absent, which is consistent with other evidence that community viewpoints and participation are minimised by those with power. Communities are hobbled by inadequate knowledge and understanding (Arnstein, 1969; Mutch, 2017). While the MOE participants (the Delivery Managers) in this study claimed the primacy of each school's Education Brief (MOE, 2020b, 'Education Infrastructure Project Brief') in the design process, other evidence suggests that bureaucratic priorities guide property planning rather than curricular and pedagogic ones (Mutch, 2017; Wells et al., 2018).

Analysis of global, European, Australian and New Zealand contexts to questions of innovative change and community consultation indicate international commonalities and illuminate the point that policy travels.

\section{Learning and Pedagogy in (and for) the $21^{\text {st }}$ Century}

Scholars, commentators, and teachers are by now accustomed to a schooling milieu that takes for granted 'a complex apparatus of electronic screens and surfaces, technical infrastructure, computing hardware [and] software' (Loveless and Williamson, 2013: 1), and accordingly, a reconceptualisation of schooling to reflect a digi-business future that replaces

\footnotetext{
${ }^{1}$ In this article, 'Innovative Learning Environment' will refer to the totality of a school built to innovative design and that is committed as a whole school to innovative practices; 'Flexible Learning Environment' will refer to the physical place of teaching and learning (the 'classroom').

2 Māori term for family, including extended family.

${ }^{3} \mathrm{~A} \mathrm{MOE}$-appointed committee consisting of persons unrelated to the proposed school but that is considered a proxy for the (new) community.
} 
the imaginary of the 9-5 factory. 'That is to say that both schools and businesses now speak the same language of flexibility, modularization, componentization, competences profiles, soft performance, brainpower, [and] problem-solving' (Loveless and Williamson, 2013: 3940). Educational facilities' design increasingly embodies these principles, with developments in educational building design that are consistent with wider technological change and reformist trends in education that emphasise the critical need to better prepare school leavers for participation in a global 'knowledge economy' (Wells et al., 2018).

The Centre for Educational Research and Innovation (CERI) of the Organisation for Economic Cooperation and Development (OECD), through its ongoing 'Innovative Learning Environments' (ILE) research programme has defined ILE as 'an organic, holistic concept-an eco-system that includes the activity and the outcomes of the learning' (OECD, 2013: 11). The 'place' of learning has thus been refocussed to include the community, retirement villages, or local business experts, seeing students, teachers, outside experts, content, facilities and technologies in relation with each other (Dumont and Istance, 2010). The principles of learning identified by its ILE research (Dumont and Istance, 2010), while chiefly concerned with approaches to teaching and learning, are relevant to school design, particularly those promoting the presence and activity of students and 'learning environments [that are] alive with the 'buzz' of collegial activity and learning' (OECD, 2017: 23). These principles acknowledge that pedagogy has evolved, prompted in part by the influence of a global digital economy that requires $21^{\text {st }}$ century schools to ensure that children and school-leavers acquire appropriate skills and dispositions, including 'flexibility, creativity, problem-solving, innovation, collaboration, continuous improvement, risk-taking, entrepreneurship, and social responsibility' (Loveless and Williamson, 2013: 40). This emphasis on educating for the $21^{\text {st }}$ century has contributed to reassessments of the infrastructure supporting teaching and learning (Könings et al., 2017; Könings and McKenney, 2017). The shift to focussing on student and learner involvement in, and engagement with, the educational process (Oblinger, 2006; Radcliffe, 2008) has been influential in encouraging building design that will support greater student agency in the learning process (Wall, 2016).

\section{Design and Pedagogical Change}

Certain uses or purposes of a designated space may be obvious. Thus, the traditional classroom inclines towards a teacher presenting from the front (Dovey and Fisher, 2014; Fisher, 2005; Nair, 2014; UCISA, 2019), whereas a Flexible Learning Environment (FLS), featuring hubs with break-out spaces and other adjacent spaces enable a wider range of possible pedagogical modes (Dovey and Fisher, 2014; Fisher, 2005; Monahan, 2002). The design of innovative educational facilities convey the hope of their designers to provide spaces of learning that create possibilities for greater collaborative, project-based learning, while also supporting personalised, individual learning (Dovey and Fisher, 2014). For the design to function as intended will require the development of spatial competence on the part of users, and should that competence be developed, the spatial phenomenon will fulfil its intention. On this view then, designers are enablers of practice, by deliberately indicating uses to the occupants of the resulting built environment-what Monahan (2002) termed, 'built pedagogy'. From a design intention perspective then, educational facilities can be considered to educate more generally (UCISA, 2019), by implicitly communicating cultural messages (Veloso et al., 2014). 
Therefore, building advancements in education facilities do not merely demonstrate advances in building technology, but represent the belief that the built learning environment matters, contributing to student well-being, teacher satisfaction and positive school culture (Moore and Lackney, 1993; Nair, 2014; Nair et al., 2013). School design should support members of a school community in feeling safe, motivated, valued and respected (Nair, 2014; Wall, 2016). Woolner et al. (2012) and Woolner et al. (2018) have warned, however, that there is not a linear relationship between building design and pedagogy, nor are pre-packaged 'off-the-shelf' replacements for traditional practices available (Kokko \& Hirsto, 2021). The complex links between material space and pedagogy highlighted by, for example, Charteris and Smardon (2018, 2019); Charteris et al. (2017); and Tondeur et al. (2017), are acknowledged by Woolner et al. (2018), who argue that less emphasis be placed on design, and more on pedagogies, such as collaborative learning and the development of an innovative school culture.

Nonetheless, learning environments research has traditionally concentrated on tangible building elements rather than on teaching and learning (Blackmore et al., 2011) or the complex social practices that characterise learning environments (Woolner et al., 2018). Furthermore, the rise of innovatively designed school buildings and learning spaces has not been complemented by adequate or convincing research into their benefits for students (Byers, 2016; Byers et al., 2018; Imms, 2016; Imms et al., 2017; Young et al., 2020). Yet all the while, at public expense, bureaucrats, policy-makers and designers promote innovative school facilities' design as a change agent, despite a paucity of research into the scholastic and social benefits of these designs. This (risky) commitment indicates that the question of the relationship between design, learning and pedagogy is not a neutral one (Veloso et al., 2014). Furthermore, studies dating to the earlier period of ILE and FLS development in Australia bear out some of the fears expressed by parents, specifically regarding auditory overload (Mealings et al., 2015), and teachers struggling to manage multiple students engaged in multiple tasks in undefined space (Chapman et al., 2014). On the other hand, children sitting under desks and occupying various informal spaces, in somewhat clandestine style, can be interpreted as a form of agentic reterritorialisation of the space by student users (Chapman et al., 2014; Charteris et al., 2017). Clearly, for the users of (re)designed innovative learning spaces, there are challenges to confront and overcome, yet there are perceived benefits. The ILETC project (Imms et al., 2017) and Byers et al. (2018) have demonstrated that flexible, non-traditional spaces are instrumental in positively supporting changed teacher attitudes, student pedagogical practices, and learning, suggesting that there is significant value in balancing innovation and risk.

\section{Community Participation}

Given what has just been suggested, it comes as little surprise to find in the New Zealand context, the anecdotally-held view of some New Zealand parents is that the development of these non-traditional spaces and associated pedagogies are needless and experimental (see, for example Eder, 2018 and King, 2019). Countering this view of reckless experimentation is the suggestion that the active participation of school communities in the processes of change is key to ensuring changed practice (Sigurđardóttir \& Hjartarson, 2016; Woolner et al., 2012), and that bringing together a range of stakeholders in participatory design exercises can positively contribute to increasing mutual understanding (Könings et al., 2017), for instance 
by clarifying why pedagogical shifts are required. Establishing a mutually-understood pedagogical vision in the design phase connects then with the suggestion that pedagogy and the learning environment be aligned (Dovey and Fisher, 2014; Könings et al., 2017; Nair, 2014; van Merriënboer et al., 2017).

These studies echo the view that 'bottom-up', participatory approaches to design planning are desirable and successful (Cleveland and Fisher, 2014; Moore and Lackney, 1993). Blackmore et al. (2011) reviewed examples of research demonstrating the realisation of the value of participatory approaches, including families, students and teachers. These findings are endorsed by the literature reviewed by Leiringer and Cardellino (2011). In their Scandinavian case studies, they demonstrated examples of significant community consultation in the development of new schools, and more recently, a Special Issue of the European Journal of Education advocated broad-based participatory engagement by communities with the design of new learning environments (Könings and McKenney, 2017).

The ambitious BSF programme, launched in 2003, aimed to rebuild and refurbish all 3500 secondary schools in England between 2005 and 2020 (Tse et al., 2015). BSF was premised on the view that the pre-existing school building stock was unable to meet the needs of $21^{\text {st }}$ century students, and that modernised building design would complement pedagogies focussed on student achievement (Mahony and Hextall, 2013). A notable feature of BSF, and of relevance to the study this article reports on, was the requirement that school communities, including students and teachers, would be widely involved and consulted through a process of educational visioning (Tse et al., 2015). The BSF programme was later shelved by the Conservative-led coalition government in 2010, following the James Review (Mahony and Hextall, 2013), due to its cost, and uncertain links between capital investment, building fabric and improved achievement outcomes (Mahony and Hextall, 2013). Also critiqued by the James Review was the vaunted consultation process, which was found to be complicated, time-consuming and ultimately made irrelevant by subsequent procurement processes, that negated the influence of schools and their wider communities (Tse et al., 2015).

Influenced by BSF and the work of the OECD, Portugal's Secondary Schools Modernisation Programme (SSMP), launched in 2007, invested significantly in renovating 332 state secondary schools by 2015 (Veloso et al., 2014). SSMP too was based on a perceived link between the quality of school buildings and improved education practice. It aimed to encourage a shift to technology-rich, innovative teaching approaches, and to provide physical facilities that could cater to increasing student diversity. Veloso et al. (2014) note that, while participation is important, it may also fail to achieve consensus, thus undermining design decisions. Although SSMP specified the 'buy-in' of schools through a process of validating design changes, as it turned out, the participation of school communities in the SSMP project was variable, with limited participation by teachers, students and parents. In the main, 'participation' was limited to school boards. For Veloso et al. (2014), the evidence ranged across collaboration, negotiation and resistance, including widespread involvement and ongoing relations with commissioned architects; the need to modify plans, requiring negotiation; and rejection, either by the school of the plans, or the architect of the school's requests for changes (Veloso et al., 2014). 
On the issue of community participation, Kim and Bryan (2017) distinguished community involvement in schools from the involvement of individual parents. It is necessary that community is emphasised, however, as schools often play critical roles in the lives of the communities they serve (Mutch, 2017), with many people in these communities sharing deep links to their local school. The experiences of many parents in typical school communities whose schools undergo significant changes do not necessarily cohere with the democratic ideal of consultation, discussion, education and negotiation (Heraud et al., 2019; Mutch, 2017; Wells et al., 2018). Indeed, principles of social order and governmental control may potentially override any commitment to community voice (Heraud et al., 2019). As Wood (2019) notes, when the legitimacy of a building programme is taken for granted by those in authority, public debate is shifted, and even silenced. At a community level, the result may instead be a sense of disempowerment and even inferiority, often exacerbated by limited information.

Arnstein's model of 'citizen participation' (1969) sheds light on this kind of marginalisation, linking the concept to urban planning case studies in the United States of America, which frequently demonstrated the 'have-nots' being side-lined, and even duped, by those with power. Arnstein conceived a ladder metaphor, consisting of eight rungs, to display three approaches to participation: non-participation, tokenism and citizen power. The objective of the lowest two rungs, namely 'manipulation' and 'therapy' 'is not to enable people to participate in planning or conducting programs, but to enable powerholders to 'educate' or 'cure' the participants' (1969: 217). Such expressions of power may well occur in schools considering major physical and pedagogical changes, where power is significant because of the significant expense to the public purse of providing school infrastructure. Therefore, the government (or other relevant authority) is the client and is arguably entitled to determine the direction and substance of the design and planning process.

This perspective was challenged by Arnstein, for whom citizen participation requires the redistribution of power to the 'have-nots', so that those "presently excluded from the political and economic processes [are] deliberately included in the future" (1969: 216). While the collective voice of a community can effect change (Kim and Bryan, 2017), collective action requires networking, an option possibly closed off to community members contending with socio-economic barriers (Holcomb-McCoy and Bryan, 2010). These circumstances also act as barriers to attendance of public meetings, contributing to low turn-outs, which can defeat the power of parents. Arnstein did acknowledge that the highest rung, 'citizen control' was aspirational rather than likely. More achievable are the two rungs below, namely 'delegated power' and 'partnership', affording citizens a major share of power and the right to hold planners and authorities to account. In reality, however, it is the rungs of 'informing' and 'consulting' (what Arnstein referred to as 'tokenism') that may characterise community experience of participation in major projects affecting neighbourhoods. Is this bleak outlook confirmed when asking some questions concerning the role of community consultation and participation in the design of innovative facilities?

\section{The New Zealand context}

In the years preceding 2010, the New Zealand Ministry of Education (MOE) developed a learning studio pilot project (2012), subsequently committing itself to a building programme 
to provide buildings designed to predetermined criteria (see Author, 2017b, for a critique). In 2016, the MOE claimed a link between building fabric and student achievement (2016), and in the period leading up to 2017, it shared and actively promoted the OECD's (2013) holistic view of innovative learning environments as an ecosystem (Author, 2017b). Since the election of a new government in November 2017, the language of 'Modern Learning Environments' (MLE), 'Innovative Learning Environments' (ILE) and 'Flexible Learning Space' (FLS) has largely disappeared ${ }^{4}$, replaced with the terminology of 'Quality Learning Environments' (QLE). The New Zealand MOE now echoes the concern of the current Labour government with 'wellbeing': 'the physical elements of a school support the delivery of its educational vision, [and] can contribute to meeting the diverse needs of learners and overall success and wellbeing at school' (MOE, 2020a, 'Designing learning environments'). The MOE continues nonetheless to recognise a relationship between teaching styles and classroom design (2020a), calling for a match between design and approaches to teaching and learning.

\section{The study}

The focus for this article falls on parents and caregivers ('parents', henceforth), and the nature of their inclusion in, or exclusion from, (re)design processes, seen through the perspectives of parents, architects and MOE officials. Parental voices are under-represented in New Zealand learning environments research, and, for that matter, so too are the voices of architects and the MOE, thus this article addresses a significant gap in learning environments research in New Zealand.

\section{Design and participants}

The study on which this article is based was designed as a small-scale qualitative study, requiring minimal resources. It was based on analysis of literature, policy and media articles, a limited parent questionnaire, and semi-structured interviews of purposively identified participants. The study participants were grouped as follows:

parents and caregivers who have children currently or recently (in the past year) enrolled in schools that have retrofitted Flexible Learning Space (a 'studio' or 'learning commons' where students and teachers work);

parents and caregivers who have children currently or recently (in the past year) enrolled in schools that were 'new builds', that is, established as Innovative Learning Environments (where the entire school consists of FLS, and was established as a self-consciously future-focussed school).

Architects or designers who have been involved in the design of both classes of school, that is, retrofit projects and new build projects.

MOE capital works officials

\footnotetext{
${ }^{4}$ Many of the links referenced in Author (2017b) refer to Ministry of Education website pages that have now simply been removed. It is as if the Ministry has erased its institutional memory.
} 
Table 1: Order and timing of participant interviews.

\begin{tabular}{|l|l|}
\hline Six architects responsible for designing multiple educational facilities in New Zealand; & $\begin{array}{l}\text { Aug } 2018- \\
\text { May } 2019\end{array}$ \\
\hline Four parents with children at refurbished schools & Nov 2018 \\
\hline Three parents with children at one ILE school & Oct 2019 \\
\hline Three MOE delivery managers ${ }^{5}$ and one senior MOE property official. & Mar 2020 \\
\hline
\end{tabular}

\section{Data analysis}

Table 1 indicates the timing of the interviews over the period of the study. These were hourlong (more or less) and digitally recorded. The transcriptions were inductively analysed to ensure openness to findings that were emerging from the field. This was important as the study encompassed the period from August 2018 to March 2020. Thematic coding followed Huberman et al. (2014). The coding framework consisted of elemental (or foundation) codes (descriptive labels, sound bites and process descriptions), and affective codes (values/attitudes/beliefs, and evaluative statements (Huberman et al., 2014).

An anonymous parent Qualtrics questionnaire was developed and remained open to 2020 . The intention was not to attract a large pool of respondents, so it was advertised only on a Facebook Group page that currently has 53 members (https://www.facebook.com/groups/324609028046681) in October 2018, and offered to parents at one ILE school in October 2019. It was re-advertised on the Facebook Group page in July 2020. The three invitations led to the survey being completed by 44 parents. The questionnaire provided both open and closed items enabling the respondents to make comments in relation to the open questions, while the closed questions required a multiplechoice selection, using a Strongly Agree to Strongly Disagree scale. The intent was not to subject the data to statistical analysis, but rather to provide results that add rigour to the study, by triangulating findings and supporting the overall process of exploration, description, and explanation, directed towards theory building. The two open ended responses were included in the Nvivo analysis of interview data.

\section{Findings}

The question of community participation in the design planning processes of innovative, nontraditional learning spaces and schools was explored from the perspectives of parents, architects, and MOE Delivery Managers. As may be expected, seventeen interviews across a range of participant categories yielded rich data that was analysed into themes pertinent to each participant group. The focus on consultation in the (re)design of educational architecture and associated pedagogies presupposes several questions, among these to do with justifications for change, with the process of change and with the results of change. Thus, for this article, findings are selected for their insight to the themes of change and community consultation. In discussion, I will reflect on how these findings illuminate innovation and risk.

\footnotetext{
${ }^{5}$ Employed by the MOE to manage the delivery of major school capital works from planning, through design, service and product procurement to completion of the project.
} 


\section{Change}

The (re)design of schools to create flexible, open and multi-use space represents a significant change for many closely associated to schools, though the concept is not entirely novel, as 'open plan' designs have been attempted in the past (Bennett and Hyland, 1979; Cameron, 1986; Cuban, 2004). The participants most enthusiastic about making these changes were the architects, and those parents who happen also to work in an ILE school. While these parents actively supported innovative approaches, they were, by virtue of their professional roles, able to share their insights gained from parents in their experience, whose attitude seems to suggest a guarded response to innovative changes in education. This response was echoed by the non-teacher parent participants, and survey respondents. 'Change for the sake of change' sums up the view of many, while a common argument (considered by some to be decisive), was the view that there is no research to support the changes: 'There's nothing demonstrating a real positive outcome for it. No purpose.' While most parent participants accepted that reconfigured spatial dimensions may give rise to student experiences that suit some students, these changes do not suit all. From a parental perspective, students either 'love it or hate it'. Those most against the change were primarily concerned for special needs students experiencing sensory overload and the general overuse of digital technology in what they saw as large, chaotic environments that lack ordered seating. At the other end of the scale was the view that 'the social development and collaboration [is] helping my child to feel happy and secure' and a sense of students' 'belonging, not just to the school but to the spaces'. These latter perspectives contradict the view of some parents that it is impossible to have quality teacher-student relationships in FLS where teachers might not have a strong grasp on individual identities within their large classes.

Of parents who responded to the questionnaire, $62 \%$ thought their children enjoyed having multiple teachers and $59 \%$ that their children enjoyed the collaborative opportunities offered by their FLS. The latter two parental responses confirm the view of the participant architects that modern school design should challenge the status quo by better reflecting the changing attitudes, expectations, and experiences of young people. Traditional schools, they suggested, are 'institutional' and preclude collaboration. The 'tight fit' designs of traditional schools make flexibility near-impossible, and costly to re-shape. Not only do traditional designs fail to recognise that teaching has changed, but their inflexible designs limit pedagogy to 'stand and deliver' approaches. Instead, 'loose fit' designs were suggested, as these enable teachers to 'make worlds within the big world'. Such designs, they variously argued, privilege the presence of students, create community, improve relationships, and connect students with the cultural significance of a school's locale.

The participant architects saw their work as providing teachers the opportunity to re-set their pedagogies, and create opportunities for team and interdisciplinary teaching (Young et al., 2020). Some parents suggested, however, that these design changes come at a cost to teachers, leading to greater work stress, with one reporting evidence of teachers erecting temporary enclosures, and being 'deemed backward facing, [and] old-fashioned, [for failing to] get with the programme'. While the MOE participants did not overtly suggest that the traditional status quo be replaced, they shared an interest in how school facilities can be improved to positively support teachers in their work and the experience students have of school. They saw the potential to add value by enhancing the quality of the building fabric. 


\section{Community Consultation}

Reference to 'community' consultation may presuppose a unitary notion, however, the MOE participants, whose role includes stakeholder management, recognised that a school's 'community' should be broadly defined. Consequently, they reported that at each location, the appointed Delivery Manager must consider who may have an interest in the school. This includes cultural and sporting groups that use the school after hours, and the neighbours, even if they are not part of the school. In their responses, the architects delineated a range of groupings under the 'community' label, referencing the Establishment Board in new (greenfield sites) schools, the Board of Trustees (BOT) ${ }^{6}$ in established schools, the parent community and the students. The architects suggested they value time spent with the students, as this is sometimes the most valuable form of consultation. As a sidebar comment, both architects and MOE officials made particular reference to working with Māori communities, where care, cultural sensitivity and inclusion are critical aspects of the working relationship.

While the MOE voice agreed in general terms that consultation can support wider acceptance of a project, these officials indicated wide consultation in most state school settings is, however, not always practical or feasible. From their professional and policy perspective, schools can influence the design of capital projects through the 'Education Brief' (MOE, 2020b, 'Education Infrastructure Project Brief') that schools use to establish their pedagogical vision in the design phase. The MOE participants understood community consultation to occur through public meetings, questionnaires, BOT meetings, strategic planning meetings, and off-site visits of other schools by members of planning teams. The scope of services offered by the MOE to schools includes the option to facilitate consultation, but, in the experience of the MOE (and architect) participants, there is variable evidence of community consultation, as individual schools manage this process as they see fit. Both Delivery Managers and architects reported that where public meetings occur, these are frequently characterised by low turn-outs.

This variability was echoed by the parent participants. Furthermore, the experience of all parent participants, whether aligned to the innovative concept or not, was of information sharing as a proxy for consultation, which, for some parent participants, fails to meet the standard they envisaged for their proper role as parents. The majority of those responding to the online questionnaire confirmed, in their experience, the lack of consultation in the design phase. Instead, 58\% confirmed that the community was not invited to become involved in the design phase, nor did the architects seek regular community input. A greater number (69\%) found that information sharing was the limit of their experience of consultation.

The experience of the information-sharing and updating that stood in place of consultation and participation reported by parent participants (interview and questionnaire), included attendance at public meetings. Some participants reported difficulties in attending meetings due to family and work commitments, possibly contributing to the low meeting turn-outs mentioned by others. Those able to attend meetings recounted the overt communication of positive innovation narratives that elevated innovation and demonised the traditional. For

\footnotetext{
${ }^{6}$ In New Zealand state-schools, a committee of elected parent representatives. Also includes the principal, a teacher representative, and, in secondary schools, a student representative.
} 
others, this narrative, presented like a 'sales pitch', was underpinned by the implicit and explicit message that not only was this direction in the best interests of the students but it was pre-decided. A number of parents (interview and questionnaire) communicated their sense that impending building developments at their school were MOE-enforced: 'the plans were purely coming from Ministry of Education and the government and this was the plan, this is what's approved, this is what will be built' stated one, while a questionnaire respondent claimed, 'I was also told funding for improvements was tied to it fitting with that modern learning philosophy.' Consequently, many responded with a mixture of anger, frustration, and resignation at worst, or have taken a 'wait and see' approach at best.

The MOE participants rejected the policy enforcement theory, and referred instead to the Education Brief, mentioned earlier. They acknowledged challenges in the 'consultation' process, suggesting difficulties may stem from the unwillingness of parties to compromise, or to acknowledge the perspectives of others. For the most part, in the experience of the MOE participants in this study, consultation occurred mainly with a team, composed usually of the principal, senior leaders in the school and members of the Board of Trustees. Some architect participants reported that relationships with the BOT or steering committee could sometimes be challenging as 'some of them think their voices are pretty important', reflecting strong parental opinions, often not grounded in research or good argument. Most challenging for some architect participants are the public 'stand-ups' (required as part of their contract with the MOE), one in particular recalling an event that was 'fraught, vicious and horrible': 'People [were] abusing me personally in public meetings'. Contrastingly, as a sidebar comment, those participants who had experience of working on kura ${ }^{7}$ projects reported these in generally favourable terms ${ }^{8}$. In these cases, the architects would usually meet the entire community, whose feedback may influence the final design. Interestingly, the architects' attitude to consulting with educators was lukewarm, primarily due to their perception that teachers are self-interested and lacking the skills required to adequately inform a design brief. A view was expressed within the architect group that the teaching staff and community are mere sojourners in the long life of a school, and therefore unlikely to (be able to) demonstrate a longitudinal vision. Besides, the ultimate commitment of the architects is to the paying client, namely the MOE. For their part, the MOE participants demonstrated a distinct avoidance of any time-consuming, overly reflective consultation processes, as these could result in project delays.

\section{Discussion}

In this discussion, I reflect on how the findings address the research question, and consider what these findings may say about innovation and risk. In the context of innovative educational facilities' designs, I have sought an exploratory sense of parents' participation in, and contribution to, the design planning processes. To do so, I sought the views of selected parents, architects and MOE Delivery Managers. The primary method of collection was semistructured interviews, supplemented by a small-scale questionnaire, completed by 44 parents.

\footnotetext{
${ }^{7}$ A Māori community school.

${ }^{8}$ This study did not include Māori kura, which are schools of 'special character', integrated into the state system, but able to operate somewhat independently of the state school system.
} 


\section{Community Consultation}

It has been made evident in this article, that the concept of 'community' is a slippery one. In the larger study on which this article is based, the conceptualisation of 'community consultation' was intended to refer primarily to parents, teachers, and students, and while this article specifically focuses on parents, many participant responses made overlapping use of these sub-categories. The Delivery Managers, for example, folded neighbours and sport groups into their definitions of 'community'. Intrinsic to the BSF and SSMP programmes was the active engagement of parents, students, and teachers, collaborating on a process of educational visioning and designing for the future educational needs of their schools (Tse et al., 2015; Veloso et al., 2014).

What is significant, however the term may be defined, is the collective conceptualisation of community, a point made by Kim and Bryan (2017) and Mutch (2017). Thus, when thinking of 'parent community', its collective voice and participation has greater significance and weight than the isolated or atomistic actions of individual parents. There was no evidence yielded by this small-scale, exploratory study to suggest, however, that the parent-participants saw themselves as members of a collective voice, speaking instead from the perspective of individual actors. Yet, if a parent community is to take on the mantle of citizen power suggested by Arnstein (1969), then its members need to be effective networkers (HolcombMcCoy and Bryan, 2010). The absence of evidence of collective response in the comments made by parent participants may help to explain their generally negative perceptions of their experiences of consultation process-as something done to them, rather than as anything they did. Despite researchers expressing a generally positive disposition towards the potential value of community consultation and participation in planning and designing new or improved school facilities (Cleveland and Fisher, 2014; Könings et al., 2017; Könings and McKenney, 2017; Moore and Lackney, 1993; Sigurđardóttir \& Hjartarson, 2016; Woolner et al., 2012), the actual experience of communities (parents are rarely mentioned) is variable at best (Veloso et al., 2014) and somewhat negative at worst (Tse et al., 2015). These outcomes seem evident in the data presented in this article.

The substantive experience of consultation as experienced by parents who took part in the study reported in this article-whether their own perspectives are positive or negativetherefore resonates strongly with Arnstein's (1969) 'tokenistic' rungs of 'informing' and 'consulting'. What counts as 'consultation' for participant parents who had experienced major retrofits, rebuilds or new builds of schools prior to this study, amounts to no more than 'receiving information', delivered in meetings that are "turned into vehicles for one-way communication by the simple device of providing superficial information, discouraging questions, or giving irrelevant answers" (Arnstein, 1969: 219). At best, on the evidence obtained in this study, the local community is provided information and 'kept in the loop', but has little to offer in formulating the actual design of either facilities or programmes the facilities will offer. Instead, key decisions are limited to small committees, just as Veloso et al. (2014) found was the experience of the SSMP programme.

Notably, comments from the participant architects suggest a hierarchy of significance, in which they show preference to working with students; have a somewhat dismissive attitude towards educators (mere sojourners more concerned with where the tote trays will stand); 
and are wary of parents' strong (uninformed and emotive) views. Furthermore, the views of the Delivery Managers, while acknowledging the role and place of the parent community in contributing to the planning and design process, suggested that their focus is on controlling the narrative and the process, to ensure that they are able to 'get the job done on time and in budget'. The BSF evidence cited by Tse at al. (2015) indicates that active community participation breaks down at the nexus of service procurement, delivery and budget. Similarly, the evidence provided in this article points to an obvious conflict of interest between the paying client (the MOE) and the public being 'served'. Arnstein (1969) demonstrated ably that on balance, the typical dynamics between the public and officialdom are seldom weighted in favour of the public being 'served'.

\section{Innovation and Risk}

ILE educational facilities are designed as visually striking buildings, characterised by open, porous internal spaces, that encourage the flow or concentration of users. These structures may be labelled as 'innovative' as akin to 'new', 'novel' and even, 'revolutionary', though 'open plan' designs are not new (Bennett and Hyland, 1979; Cameron, 1986; Cuban, 2004). Accordingly, some parent participants held the view that ILE simply re-enact the discredited 'open-plan' experiment of the 1960s and 1970s (mentioned too by Imms, 2016). These critiques are not compelling, however, as they ignore advances in building technology, digital technology and teachers' pedagogy. Besides, amongst the architect and MOE participants, was a ready recognition of the limitations of 'open barns', a view echoed by Osborne (2019).

The arguments put forward by the architects in this study that modern, flexible designs create opportunities to build relationships and community, and give students a sense of self-worth, resonate with various sources claiming that the plaza-style and large social spaces characteristic of innovative facilities design can be a medium to encourage positive citizenship qualities (Nair, 2014; Nair et al., 2013) and create a sense of community (Leiringer and Cardellino, 2011; Tanner, 2009; UCISA, 2019). Claims by the architect participants that innovative design can enable pedagogical shifts are echoed in a range of literature (Dovey and Fisher, 2014; Fisher, 2005; Imms, et al., 2016; Nair, 2014; Tanner, 2009). In the New Zealand context, these claims have been supported by the MOE (MOE, 2011; TKI, nd. (b); Wall, 2016). In respect to the links between innovation and pedagogical change, there is, however, adequate research evidence challenging the view of there being a linear relationship between the two. Woolner et al. (2012) and Woolner et al. (2018) specifically warn against this view, whilst Sigurðardóttir \& Hjartarson's (2016) study of multiple schools suggested wide retention of traditional practices or defaulting back to those practices post-change implementation. Similarly, the SSMP study of Veloso et al. (2014) found that despite many positive outcomes arising from innovative change, teaching practices in schools retained their traditional basis.

As the findings reported in this article suggest, the participant architects and those parents supportive of innovation, opined on the benefits they believed innovative learning space design, coupled with appropriate pedagogical approaches, could deliver to students. These views were, however, challenged by other parental comment. Around half of those parents who responded to the questionnaire reported concerns with declining concentration levels and stalled academic progress of their own children. Conversely, some questionnaire respondents recognised that flexible design features can create opportunities not otherwise 
possible to support learning, such as the simultaneous presence of two, three or even four teachers. Yet for some parents, this feature in fact leads to relationships breaking down. Critical interview and questionnaire comment specifically expressed concerns for students with additional learning needs - a concern not noted in the research used in support of this article. Despite the small-scale nature of this study, there thus remains some room for doubt and scepticism, calling into question the risk associated with significant capital investment in buildings on the assumption that one of its benefits will be to have a positive influence on student outcomes, when there are simply too many other factors at play (Veloso et al., 2014; Wall, 2016).

\section{Conclusion}

The evidence presented in this article indicates that active parental participation in the process of planning for and designing major capital school redevelopments or new developments is unlikely for most parents, being limited, at best, to selected representatives on a school Board of Trustees. Further evidence indicates that, in the contexts under examination, parental participation is not always possible, or, at worst, is intentionally not sought. For the most part, parents' experience is of attendance at public meetings, when information sharing and progress updates are a proxy for consultation. As Arnstein (1969) realised, 'participation' is frequently a ritual allowing officialdom to claim that consultation has occurred, yet while maintaining the status quo. Consequential outcomes of such avoidance or neglect of parental participation include the marginalisation of parents who feel dragooned into accepting changes to either facilities or pedagogical and learning practice they regard as negatively impactful on their children.

Further questions remain, not only in the New Zealand context, but more generally. One of these questions is to apply the focussing question to teachers (and students). Another is to take seriously the view of the participant architects that teachers and parents have little of value to offer to a project that is required to have a life span of at least fifty years: are parents and teachers too self-interested to make a valid contribution to the design of new, flexible learning spaces and the pedagogical practices that will be enabled by these spaces? Is the added cost that consultation will add to planning justified by the potential benefits of consultation? What talents, skills and knowledge are required by parents, teachers and students to fully engage in educational design planning processes? There are doubtless other questions. It is notable that, among the European literature and examples reviewed for this article, there are instances of wide consultation processes, though many of these were linked to specific case studies. Of interest then is whether there are state or country-wide instances of broad-based consultation and participation processes in European settings or elsewhere. Finally, then, can consultation processes be mandated at a national level, or is consultation and participation in educational design bound to be deeply contextualised? 


\section{References}

Arnstein SR (1969) A ladder of citizen participation. Journal of the American Planning Association, 35(4): 216-224.

Bennett N and Hyland T (1979) Open plan: Open education? British Educational Research Journal 5(2): 159-166.

Byers T (2016) A quasi-experimental and single-subject research approach as an alternative to traditional post-occupancy evaluation of learning environments. In Imms W, Cleveland B and Fisher $\mathrm{K}$ (eds) Evaluating Learning Environments: Snapshots of Emerging Issues, Methods and Knowledge. Rotterdam: Sense Publishers, pp. 117-130.

Byers T, Hartnell-Young E, and Imms W (2018) Empirical evaluation of different classroom spaces on students' perceptions of the use and effectiveness of 1-to-1 technology. British Journal of Educational Technology 49(1): 153-164.

Cameron P (1986) Ten years of open plan. Set: Research information for teachers, 1: 3-19. Available at: https://www.nzcer.org.nz/nzcerpress/set/articles/ten-years-open-plan (accessed 5 December 2020).

Chapman A, Randell-Moon H, Campbell M, and Drew C (2014) Students in space: Student practices in non-traditional classrooms. Global Studies of Childhood, 4(1): 39-48.

Charteris J, and Smardon D (2018) "Professional learning on steroids": Implications for teacher learning through spatialised practice in New Generation Learning Environments. Australian Journal of Teacher Education 43(12).

Charteris J, and Smardon D (2019) Dimensions of agency in New Generation Learning Spaces: Developing assessment capability. Australian Journal of Teacher Education 44(7).

Charteris J, Smardon D, and Nelson E (2017) Innovative learning environments and new materialism: A conjunctural analysis of pedagogic spaces. Educational Philosophy and Theory 49(8): 808-821.

Cleveland B, and Fisher K (2014) The evaluation of physical learning environments: a critical review of the literature. Learning Environments Research 4(17): 1-28.

Cuban L (2004) The open classroom. Available at: https://educationnext.org/theopenclassroom/ (accessed 5 December 2020).

Dovey K, and Fisher K (2014) Designing for adaptation: The school as socio-spatial assemblage. The Journal of Architecture 19(1): 43-63.

Dumont $\mathrm{H}$ and Istance D (2010) Analysing and designing learning environments for the $21^{\text {st }}$ century. In Dumont H, Istance D and Benavides F (eds) The Nature of Learning: Using Research to Inspire Practice. Paris: Organisation for Economic Cooperation and Development Publishing, pp. 19-34. Available at: http://www.oecd.org/education/ceri/thenatureoflearningusingresearchtoinspirepract ice.htm (accessed 5 December 2020).

Eder J (2018, May 2) 'My child is not a guinea pig': Parents want proof 'experimental' classrooms work. The Marlborough Express. Available at: 
https://www.stuff.co.nz/national/education/101994384/my-child-is-not-a-guinea-pigparents-want-proof-experimental-classrooms-work (accessed 5 December 2020).

Fisher K (2005) Linking pedagogy and space [Slide presentation]. Available at: http://www.education.vic.gov.au/Documents/school/principals/infrastructure/pedag ogyspace.pdf (accessed 5 December 2020).

Heraud R, Gibbons A, Breen G, Deerness S, Gilligan M-J, and Denton A (2019) Politics and place: Listening to the built learning environment. Policy Futures in Education 17(4): 474-488.

Holcomb-McCoy C and Bryan J (2010) Advocacy and empowerment in parent consultation: Implications for theory and practice. Journal of Counseling \& Development, 88(3): 259268.

Huberman AM, Miles MB \& Saldaña J (2014) Fundamentals of Qualitative Data Analysis. Thousand Oaks: SAGE.

Imms W (2016) New Generation Learning Environments: How can we find out If what works is working? In Imms W, Cleveland B and Fisher $\mathrm{K}$ (eds) Evaluating Learning Environments: Snapshots of Emerging Issues, Methods and Knowledge. Rotterdam: Sense Publishers, pp. 21-34.

Imms W, Cleveland B and Fisher K (2016) Pursuing that elusive evidence about what works in learning environment design. In Imms W, Cleveland B and Fisher K (eds) Evaluating Learning Environments: Snapshots of Emerging Issues, Methods and Knowledge. Rotterdam: Sense Publishers, pp. 3-18.

Imms W, Mahat M, Byers T and Murphy D (2017) Type and Use of Innovative Learning Environments in Australasian Schools. (ILETC Survey No. 1). University of Melbourne, LEaRN. Available at: http://www.iletc.com.au/publications/reports (accessed 5 December 2020).

Kim J and Bryan J (2017) A first step to a conceptual framework of parent empowerment: Exploring relationships between parent empowerment and academic performance in a national sample. Journal of Counseling \& Development, 95(2): 168-179.

King K (2019, March 6) Innovative Learning Environments - where's the evidence? Education Central. Available at: https://educationcentral.co.nz/innovative-learningenvironments-wheres-the-evidence-3/ (accessed 5 December 2020).

Kokko, A.K., \& Hirsto, L. (2021). From physical spaces to learning environments: processes in which physical spaces are transformed into learning environments. Learning Environments Research, 24(1): 71-85 https://doi.org/10.1007/s10984-020-09315-0

Könings KD, Bovill C and Woolner P (2017) Towards an interdisciplinary model of practice for participatory building design in education. European Journal of Education 52(3): 306317.

Könings KD and McKenney S (2017) Editorial: Participatory design of (built) learning environments. European Journal of Education 52(3): 247-252. 
Leiringer R and Cardellino P (2011) Schools for the twenty-first century: School design and educational transformation. British Educational Research Journal 37(6): 915-934.

Loveless A and Williamson B (2013) Learning Identities in a Digital Age: Rethinking Creativity, Education and Technology. New York: Routledge.

Mahony P and Hextall I (2013) 'Building Schools for the Future': 'Transformation' for social justice or expensive blunder? British Educational Research Journal 39(5): 853-871.

Mealings K, Buchholz J, Demuth K and Dillon H (2015) Investigating the acoustics of a sample of open plan and enclosed kindergarten classrooms in Australia. Applied Acoustics, 100: 95-105.

Ministry of Education [MOE] (2011) The New Zealand School Property Strategy 2011-2021. Available https://ndhadeliver.natlib.govt.nz/delivery/DeliveryManagerServlet?dps pid=IE74172 $\underline{32}$ (accessed 5 December 2020).

Ministry of Education [MOE] (2012) Learning Studio Pilot Review. Available at: http://www.education.govt.nz/assets/Documents/PrimarySecondary/Property/Design/Flexible-learning-spaces/LearningStudioPilotReview.pdf (accessed 5 December 2020).

Ministry of Education [MOE] (2016) Flexible Learning Spaces: How the Design of Spaces can Help Student Achievement. [Factsheet]. Available at: http://www.education.govt.nz/assets/Documents/Primary-

Secondary/Property/Design/Flexible-learning-spaces/FLS-How-the-design-of-spacescan-help-student-achievement.pdf (accessed 5 December 2020).

Ministry of Education [MOE] (2020a) Designing Learning Environments. Available at: https://www.education.govt.nz/school/property-and-transport/projects-anddesign/design/designing-learning-environments/ (accessed 5 December 2020).

Ministry of Education [MOE] (2020b) Education Infrastructure Design Guidance Documents. Available at: https://www.education.govt.nz/school/property-and-transport/projectsand-design/design/design-standards/education-infrastructure-design-guidancedocuments/\#project-brief-template (accessed 5 December 2020).

Monahan, T. (2002). Flexible space \& built pedagogy: Emerging IT embodiments. Inventio 4(1): 1-19. Available at: https://publicsurveillance.com/papers/built pedagogy.pdf (accessed 5 December 2020).

Moore GT and Lackney JA (1993) School design: Crisis, educational performance and design applications. Children's Environments 10(2): 99-112.

Mutch C (2017) Winners and losers: School closures in post-earthquake Canterbury and the dissolution of community. Waikato Journal of Education 22(1): 73-95.

Nair P (2014) Blueprint for Tomorrow: Redesigning Schools for Student-Centered Learning. Cambridge: Harvard Education Press.

Nair P, Fielding R and Lackney J (2013) The Language of School Design: Design Patterns for $21^{\text {st }}$ Century Schools ( $3^{\text {rd }}$ ed.). Minneapolis: DesignShare 
Oblinger D (2006) Space as a change agent. In Oblinger D and Lippincott J (eds) Learning Spaces. Available at: Brockport Bookshelf, pp. 1-4. https://digitalcommons.brockport.edu/cgi/viewcontent.cgi?article=1077\&context=bo okshelf (accessed 5 December 2020).

Organisation for Economic Cooperation and Development [OECD] (2013) Innovative Learning Environments. Paris: Educational Research and Innovation, OECD Publishing. Available at: http://dx.doi.org/10.1787/9789264203488-en (accessed 5 December 2020).

Organisation for Economic Cooperation and Development [OECD] (2017) The OECD Handbook for Innovative Learning Environments. OECD Publishing. Available at: http://www.oecd.org/education/the-oecd-handbook-for-innovative-learningenvironments-9789264277274-en.htm (accessed 5 December 2020).

Osborne M (2019, March 6) Innovative Learning Environments - Here's the Evidence. Education Central. Available at: https://educationcentral.co.nz/innovative-learningenvironments-heres-the-evidence/ (accessed 5 December 2020).

Parata H (2013, Sept 25). Plan to Transform School Property [Press Release]. Available at: https://www.beehive.govt.nz/release/plan-transform-school-property (accessed 5 December 2020).

Radcliffe D (2008) A pedagogy-space-technology (PST) framework for designing and evaluating learning places. In Radcliffe D, Wilson W, Powell D and Tibbetts B (eds) Learning Spaces in Higher Education: Positive Outcomes by Design. St. Lucia, QLD: Australian Learning and Teaching Council, pp. 9-16. Available at: https://static1.squarespace.com/static/55d3f590e4b0d60074069c3d/t/5cca4874c830 253749556752/1556760973074/UQ+Next+Generation+Book.pdf $\quad$ (accessed 5 December 2020).

Sigurđardóttir, A.K. \& Hjartarson, T. (2016). The idea and reality of an innovative school: From inventive design to established practice in a new school building. Improving Schools 19(1), 62-79. doi: 10.1177/1365480215612173

Tanner C K (2009) Effects of school design on student outcomes. Journal of Educational Administration 47(3): 376-394.

Te Kete Ipurangi [TKI] (nd) (a) Planning Innovative Learning Environments. Available at: https://www.inclusive.tki.org.nz/guides/planning-innovative-learning-environmentsiles/ (accessed 5 December 2020).

Te Kete Ipurangi [TKI] (nd) (b) Understanding Pedagogy as Integral to Innovative Learning Environments. Available at: https://www.inclusive.tki.org.nz/guides/planninginnovative-learning-environments-iles/understanding-innovative-learningenvironments/ (accessed 5 December 2020).

Tondeur J, Herman F, De Buck M and Triquet K (2017) Classroom biographies: Teaching and learning in evolving material landscapes (c. 1960-2015). European Journal of Education 52(3): 280-294. 
Tse, H.M., Learoyd-Smith, S., Stables, A., \& Daniels, H. (2015). Continuity and conflict in school design: a case study from Building Schools for the Future. Intelligent Buildings International, 7(2-3), 64-82, doi: 10.1080/17508975.2014.927349

Universities and Colleges Information Systems Association [UCISA] (2019) The UK Higher Education Learning Space Toolkit. Available at: https://www.ucisa.ac.uk/resources/theuk-higher-education-learning-space-toolkit (accessed 5 December 2020).

van Merriënboer JJG, McKenney S, Cullinan D and Heuer J (2017) Aligning pedagogy with physical learning spaces. European Journal of Education 52(3): 253-267.

Veloso L, Marques JS and Duarte A (2014) Changing education through learning spaces: impacts of the Portuguese school buildings' renovation programme. Cambridge Journal of Education 44(3): 401-423.

Wall G (2016) The Impact of Physical Design on Student Outcomes. (Report commissioned by the Ministry of Education). Wellington: Ministry of Education. Available at: https://www.education.govt.nz/assets/Documents/Primary-

Secondary/Property/Design/Flexible-learning-spaces/FLS-The-impact-of-physicaldesign-on-student-outcomes.pdf (accessed 5 December 2020).

Wells A, Jackson M and Benade L (2018) Modern Learning Environments: Embodiment of a disjunctive encounter. In Benade $L$ and Jackson $M($ eds) Transforming Education: Design and Governance in Global Contexts. Singapore: Springer Nature, pp. 3-17.

Wood A (2019) Built policy: school-building and architecture as policy instrument. Journal of Education Policy 35(4): 465-484.

Woolner P, McCarter S, Wall K and Higgins S (2012) Changed learning through changed space: When can a participatory approach to the learning environment challenge preconceptions and alter practice? Improving Schools 15(1): 45-60.

Woolner, P., Thomas, U., \& Tiplady, L. (2018) Structural change from physical foundations: The role of the environment in enacting school change. Journal of Educational Change 19, 223-242. https://doi.org/10.1007/s10833-018-9317-4

Young F, Cleveland B and Imms W (2020) The affordances of innovative learning environments for deep learning: educators' and architects' perceptions. The Australian Educational Researcher 47: 693-720 